\title{
New records of four reptile species (Lepidosauria, Squamata) from the province of Guayas, southwestern Ecuador
}

\author{
Keyko Cruz-García ${ }^{1}$, Diego F. Cisneros-Heredia ${ }^{2,3,4}$, Juan C. Sánchez-Nivicela ${ }^{3,4,5}$, \\ Luis Amador ${ }^{6,7,8}$
}

\begin{abstract}
1 Universidad de Guayaquil, Facultad de Ciencias Naturales, Escuela de Biología, Av. Raúl Gómez Lince s/n and Av. Juan Tanca Marengo, Guayaquil, Ecuador. 2 Universidad San Francisco de Quito, Colegio de Ciencias Biológicas y Ambientales, Quito 170901, Ecuador. 3 Universidad San Francisco de Quito, Instituto de Diversidad Biológica Tropical (iBIOTROP), Museo de Zoología \& Laboratorio de Zoología Terrestre, Quito, Ecuador. 4 Instituto Nacional de Biodiversidad del Ecuador, calle Rumipamba 341 y Av. de los Shyris, Quito, Ecuador. 5 Universidad Nacional de Colombia, Facultad de Ciencias, Bogotá D.C., Colombia; Grupo de Investigación Evolución y Ecología de Fauna Neotropical. 6 Universidad Austral de Chile, Facultad de Ciencias, Instituto de Ciencias Ambientales y Evolutivas, Valdivia, Chile. 7 Universidad Austral de Chile, Facultad de Ciencias, Escuela de Graduados, Programa de Doctorado en Ciencias, mención Ecología y Evolución, Av. Eduardo Morales Miranda s/n, Edificio Emilio Pugín, Campus Isla Teja, Valdivia, Chile. 8 Universidad Laica Vicente Rocafuerte de Guayaquil, Avenida de Las Américas, apdo. 11-33, Guayaquil, Ecuador.
\end{abstract}

Corresponding author: Luis Amador, amadoroyola@gmail.com

\begin{abstract}
We report the southernmost record of Rhinobothryum bovallii (Andersson, 1916) and new records and notes on the geographic distribution of Anolis lyra Poe, Velasco, Miyata \& Williams, 2009, Corallus blombergi (Rendahl \& Vestergren, 1941), and Spilotes megalolepis Günther, 1865, provided from specimens collected in the Cerro de Hayas forest, province of Guayas, southwestern Ecuador.
\end{abstract}

\section{Keywords}

Anolis, biogeography, Corallus, Lepidosauromorpha, Neotropics, Rhinobothryum, Spilotes.

\section{Introduction}

Neotropical forests support the greatest number of living species in the world (Brown 2014; Andresen et al. 2018). The tropical forest of western Ecuador is home to more than 190 species of reptiles, representing 39\% of the reptile species richness in the country (Reyes-Puig et al. 2017; Torres-Carvajal et al. 2020). Although our knowledge of the diversity and natural history of reptiles in western Ecuador is limited, important herpetological discoveries have been made in recent years, such as new species and significant expansion of the geographic range extensions of previously recorded species (e.g. Jadin et al. 2009; Cisneros-Heredia et al. 2010; OrtegaAndrade et al. 2010; Passos et al. 2012; Torres-Carvajal et al. 2012, 2015; Ayala-Varela et al. 2014; Yánez-Muñoz et al. 2014, 2018; Cisneros-Heredia and Romero 2015; Pyron et al. 2015; Salazar-Valenzuela et al. 2015; CruzGarcía 2017; Cruz et al. 2017; Arteaga et al. 2017, 2018; Reyes-Puig et al. 2019).

The province of Guayas is a geopolitical division in western Ecuador and supports the largest human 
population in the country (INEC 2018). It is in the Tumbes-Chocó-Magdalena biodiversity hotspot and has a varied environment and geography, producing different ecosystems, including moist forests, dry forests, mangroves, and coastal marine areas (Mittermeier et al. 2004, 2011; MAE 2012). Habitat change and loss due to anthropogenic activities, such as unsustainable agricultural practices, urban expansion, illegal or unsustainable natural resources extraction, have impacted over two-thirds of the province. Native vegetation in Guayas covers approximately $37 \%$ of its area, and most forest fragments are unprotected, except for a few private reserves (Camacho et al. 2011; Larrea et al 2015).

Despite these serious conservation issues, forest fragments in Guayas still harbor a diverse, poorly known and threatened fauna. We present new records of Anolis lyra Poe, Velasco, Miyata \& Williams, 2009, Rhinobothryum bovallii (Andersson, 1916), and Spilotes megalolepis Günther, 1865, and extend these three species' geographical ranges to the western lowlands in southern Ecuador. A new record of the little-known and threatened Blomberg's Tree Boa, Corallus blombergi (Rendahl \& Vestergren, 1941), is also documented.

\section{Methods}

Herpetological surveys were carried out in the Cerro de Hayas Provincial Natural Recreation Area, which is in the foothills of the Molleturo-Mollepungo mountain range, Naranjal county, province of Guayas, Ecuador. Cerro de Hayas is a private reserve protecting $3.78 \mathrm{~km}^{2}$ of semideciduous lowland forests in hilly landscapes with streams and waterfalls. The reserve is surrounded by agricultural areas. It is one of the few tropical humid forest relicts remaining in Guayas and is currently threatened by mining, logging, and illegal hunting.

Fieldwork was conducted between December 2015 and March 2016, and in November 2019. Following Gallina and López-González (2011), three $150 \mathrm{~m}$ visual transects were established and sampled during day (11h00-14h00) and night (19h30-23h00) by two researchers each. The transects were separated from each other by $500 \mathrm{~m}$ and sampled in a period of one hour each. Transects were located in forest patches and crossed water bodies (including small waterfalls), hunter trails, and forest gaps. Specimens were captured by hand, photographed, euthanized with an anesthetic solution of $2 \%$ roxicain, fixed in $10 \%$ formalin, and preserved in $70 \%$ alcohol.

Specimens are deposited in two zoological museums in Ecuador: Museo de Zoología, Universidad del Azuay (MZUA; Cuenca) and Museo de Zoología, Universidad San Francisco de Quito (ZSFQ; Quito). The geographic coordinates and elevation data were obtained with a GPS unit Garmin GPSMAP 62st. Updated distribution maps were created for each species using QGIS v3.4 (QGIS Development Team 2019). The previous records and their references are summarized in Table 1.
Measurements of snout-vent length (SVL) were taken with digital calipers and rounded to the nearest 0.1 $\mathrm{mm}$ for small specimens, and with a tape measure for longer specimens. We followed measurement protocols specific for each species (Henderson et al. 2001; Poe et al. 2009; Pazmiño-Otamendi 2019; Rodríguez-Guerra 2019). Maturity and sex were determined by eversion and exposure of sexual organs.

\section{Results}

The records of Anolis lyra, Rhinobothryum bovallii, and Spilotes megalolepis from Cerro de Hayas are the first in the province of Guayas and in the Cordillera de la Costa, an isolated mountain range running parallel to the Andes along the coast of Ecuador. They also fill gaps in the distributions of these species across western Ecuador. The distribution range of $R$. bovallii is extended to the south. The new record of Corallus blombergi from Cerro de Hayas is important because of the scarcity of information available for this threatened species.

Squamata, Sauria, Dactyloidae

\section{Anolis lyra Poe, Velasco, Miyata \& Williams 2009}

Figures 1a, 2a; Table 1

New records. ECUADOR • 1 adult female, SVL 76 mm; Guayas, Naranjal, Molleturo-Mollepungo mountain, Cerro de Hayas Provincial Natural Recreation; -02.7308, -079.6286; alt. 120 m; 13 March 2016; Keyko Cruz-García leg.; at night on tree leaves 3-4 m above ground level; MZUA.Re0387 • 1 adult female, SVL $64 \mathrm{~mm}$; same data as above, except: MZUA.Re0388 1 adult female, SVL $62 \mathrm{~mm}$; same data as above, except: in daytime on a tree trunk next to a stream while displaying to another individual $5 \mathrm{~m}$ above it; MZUA.Re0391.

Identification. Anolis lyra (Fig. 2a) is distinguished from other South American Anolis species by the combination of the following characters: dewlap blue-white in females and red in males, small and with a large black central mark; lyre-shaped occipital mark. It is distinguished from the similar A. vittigerus Cope, 1862, by having smaller dorsomedial scales; semicircular scales between supraorbitals (absent in A vittigerus); $=4.1$ scales between interparietal and supraorbital semicircles ( = 2.4 in A. vittigerus); lateral stripes extending to axilla (to thigh in $A$. vittigerus); and a conspicuous lyre-shaped mark (absent or faint in $A$. vittigerus) (Poe et al. 2009).

Remarks. A fourth individual, which was not collected, was observed on a tree trunk during the day. Anolis lyra has been reported from the western slopes of the Cordillera Occidental from Colombia to extreme southwestern Ecuador (Poe et al. 2009; Yánez-Muñoz et al. 2014). Cerro de Hayas is $54 \mathrm{~km}$ north of the southernmost known record of $A$. lyra (Cascadas de Manuel, province of El Oro; Yánez-Muñoz et al. 2014) and 240 km south of 

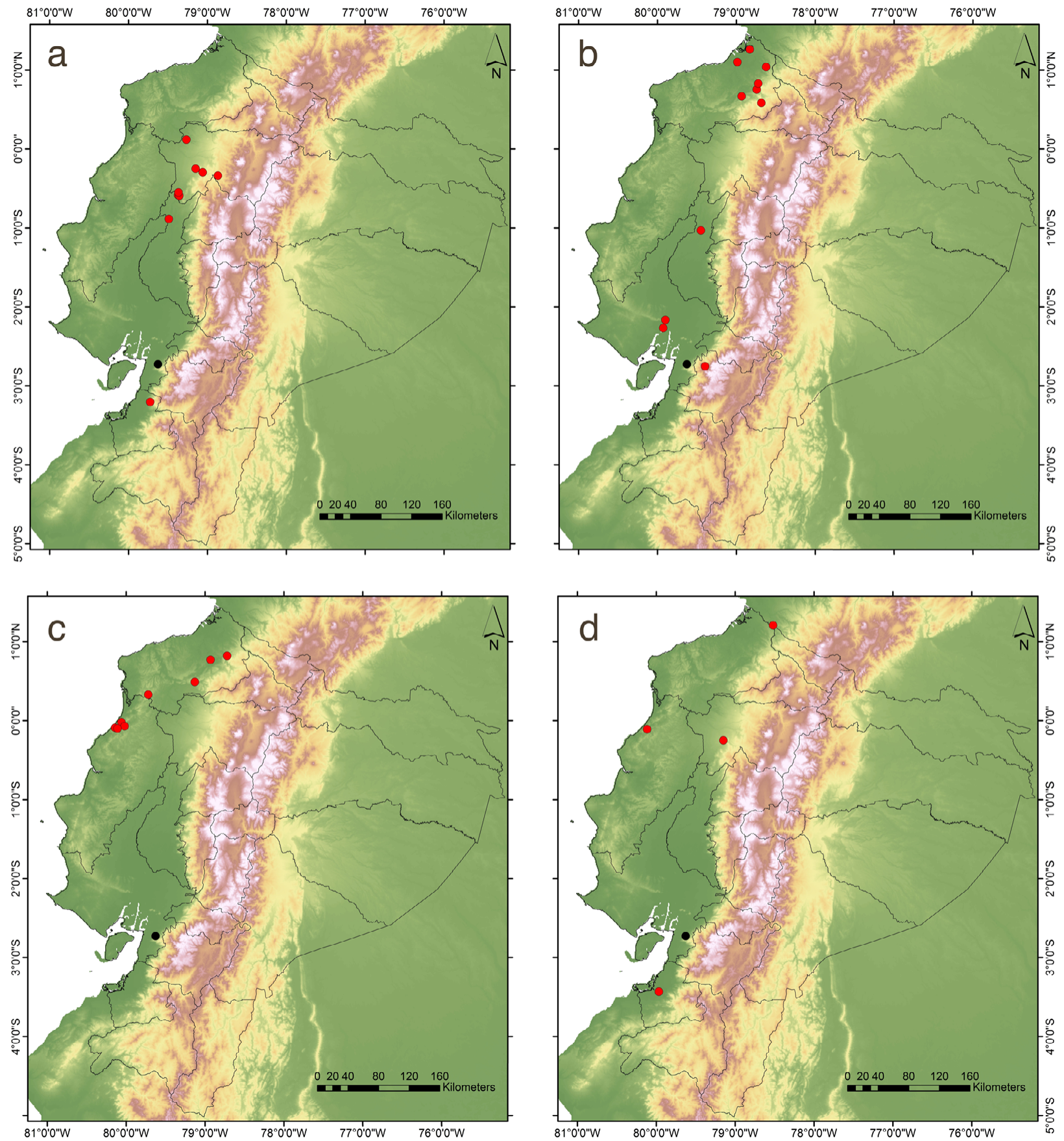

Figure 1. Geographic distribution of species in Ecuador. Red circles indicate the previously published records. Black circles indicate the new records. a. Anolis lyra. b. Corallus blombergi. c. Rhinobothryum bovallii. d. Spilotes megalolepis.

the nearest locality to the north (Río Palenque, province of Los Ríos; Poe et al. 2009).

Squamata, Serpentes, Boidae

\section{Corallus blombergi (Rendahl \& Vestergren, 1941)}

Figures $1 b, 2 b$; Table 1

New record. ECUADOR • 1 subadult male, SVL 466 $\mathrm{mm}$; Guayas, Naranjal, Molleturo-Mullepungo mountain, Cerro de Hayas Provincial Natural Recreation; $-02.7316,-079.6319$; alt: $138 \mathrm{~m}$; 10 June 2016 at 22h32; Keyko Cruz-García leg.; at night moving $6 \mathrm{~m}$ above forest floor, among branches of a Ficus citrifolia tree, next to a stream; MZUA.Re0383.
Identification. Corallus blombergi (Fig. 2b) is distinguished from Boa imperator Daudin, 1803, the only other boid in its distribution range, by the following combination of characters: absence of nasals in contact; subcaudal scales 76-86 (47-69 in B. imperator); rows of dorsal scales 50-55 (56-79 in B. imperator); ventral scales 251-269 (225-253 in B. imperator); dorsum dusky red with round red spots with dark gray margins along the body, not contacting ventral scales (gray body with large spots in B. imperator); venter orange; eyes red; snout with thermoreceptive furrows in the corners of the lips (absent in B. imperator); anal plate divided (Henderson et al. 2001; Rodríguez-Guerra 2019).

Remarks. Corallus blombergi inhabits the Pacific 

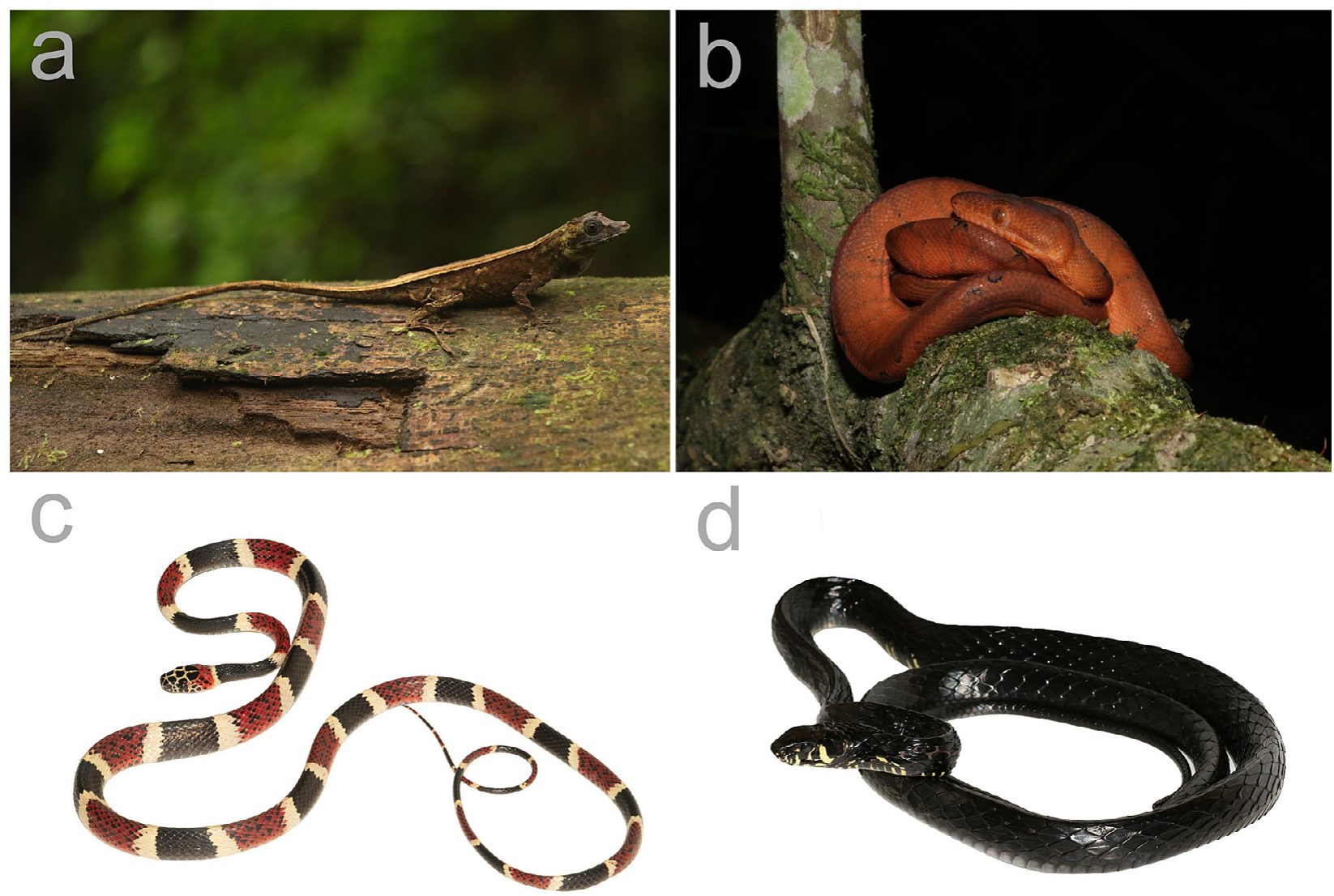

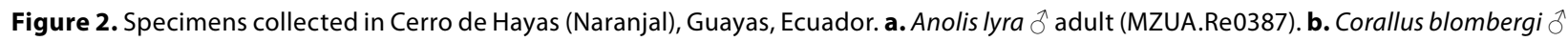
subadult (MZUA.Re0383). c. Rhinobothryum bovallii $\widehat{\partial}$ adult (ZSFQ 4081). d. adult Spilotes megalolepis $\widehat{\partial}$ (MZUA.Re0378).

lowlands from southwestern Colombia to central-western Ecuador (Pérez-Santos and Moreno 1991; Henderson 1997; Henderson et al. 2001; Valencia et al. 2008; PintoErazo and Media-Rangel 2018). The species was previously known in Guayas, but we consider it important to report this record due to the limited information available for this species, which is classified as Endangered by the International Union for Conservation of Nature (IUCN) Red List of Threatened Species (Pérez-Santos and Moreno 1991; Henderson 1997; Henderson et al. 2001; Cisneros-Heredia 2016). Our record is $26 \mathrm{~km}$ west of the southernmost record of the species in MolleturoMollopungo Protected forest, province of Azuay.

Squamata, Serpentes, Colubridae

\section{Rhinobothryum bovallii (Andersson, 1916)}

Figure 1c, 2c; Table 1

New record. ECUADOR • 1 adult male, SVL 1170 $\mathrm{mm}$; Guayas, Naranjal, Molleturo-Mollepungo mountain, Cerro de Hayas Provincial Natural Recreation; $-02.7308,-079.6286$, alt. 110 m; 02 November 2019 at 20h25; Keyko Cruz-García leg.; at night moving on the ground next to a secondary road, near a creek; ZSFQ 4081 .

Identification. Rhinobothryum bovallii (Fig. 2c) differs from similar snakes within its distribution range of distribution, such as Dipsas gracilis (Boulenger, 1902), and from its congener $R$. lentiginosum (Scopoli, 1875), by the combination of the following characters: upper scales of head black with white borders (head completely black or black scattered with reddish brown in $D$. gracilis); body pattern with black, white and large red bands, the red bands with scattered black scales (small red bands in $R$. lentiginosum); dorsal scales in 21 rows, smooth anteriorly but becoming keeled posteriorly (Peters 1960; Touzet and Cisneros-Heredia 1998; Harvey 2008; Pazmiño-Otamendi 2019).

Remarks. This species has been reported in Ecuador in the provinces of Esmeraldas, Manabí, Carchi and Imbabura (Pérez-Santos and Moreno 1991; Touzet and Cisneros-Heredia 1998; Ortega-Andrade et al. 2010; Arredondo et al. 2017; Pazmiño-Otamendi 2019). Our record is the southernmost record of $R$. bovallii, $294 \mathrm{~km}$ south of the nearest record of the species (Reserva Ecológica JamaCoaque, province of Manabí; Lynch et al. 2016).

\section{Spilotes megalolepis Günther, 1865}

Figures 1d, 2d; Table 1

New record. ECUADOR • 1 adult male, SVL 1813 mm; Guayas, Naranjal, Molleturo-Mollepungo mountain, Cerro de Hayas Provincial Natural Recreation; -02.7339, -079.6290; alt. 250 m; 23 February 2016 at 11h31; Keyko Cruz-García leg.; in daytime moving among the leaf litter, approximately $10 \mathrm{~m}$ above the waterfall plunge pool; MZUA.Re0378. 
Table 1. List of historical localities in Ecuador of the reptile species reported in this work.

\begin{tabular}{|c|c|c|c|c|c|c|c|}
\hline Species & Province & Locality & Latitude & Longitude & $\begin{array}{l}\text { Eleva- } \\
\text { tion }(m)\end{array}$ & Museum number & References \\
\hline Anolis lyra & Pichincha & Puerto Quito & 00.117 & -079.267 & 750 & $\begin{array}{l}\text { MCZ 164416, 165209, } \\
165210,171160\end{array}$ & Poe et al. 2009 \\
\hline Anolis lyra & Santo Domingo de los Tsáchilas & Finca La Victoria & 00.338 & -078.868 & & MCZ 80954 & Poe et al. 2009 \\
\hline Anolis lyra & Santo Domingo de los Tsáchilas & Sto. Domingo de los Tsachilas (City) & -00.250 & -079.150 & & $\begin{array}{l}\text { MCZ 164421, 164420, } \\
124407\end{array}$ & Poe et al. 2009 \\
\hline Anolis lyra & Santo Domingo de los Tsáchilas & Hotel Tinalandia & -00.296 & -079.060 & & $\begin{array}{l}\text { MCZ 152434, 145267, } \\
145263\end{array}$ & Poe et al. 2009 \\
\hline Anolis lyra & Los Ríos & Los Ríos & -00.585 & -079.372 & & MCZ 146995 & Poe et al. 2009 \\
\hline Anolis lyra & Los Ríos & Buena Fe & -00.888 & -079.489 & & MCZ 146994 & Poe et al. 2009 \\
\hline Anolis lyra & Los Ríos & Centro Científico Río Palenque & -00.550 & -079.367 & 1179 & MCZ 152433, 145867 & Poe et al. 2009 \\
\hline Anolis lyra & ElOro & Cascadas de Manuel & -03.206 & -079.726 & 197 & DHMECN 10983 & Yánez-Muñoz et al. 2014 \\
\hline Corallus blombergii & Azuay & Molleturo Mullopungo & -02.754 & -079.397 & 256 & UDA-AMARU 0019 & Valencia et al. 2008. \\
\hline Corallus blombergii & "Ecuador" & "Ecuador" & & & & AMNH 61754 & Henderson et al. 2001 \\
\hline Corallus blombergii & Los Ríos & Quevedo & -01.033 & -079.450 & & USNM 204087 & Henderson et al. 2001 \\
\hline Corallus blombergii & Esmeraldas & Norte de Borbón & 01.260 & -078.830 & & QCAZR6401 & Rodríguez-Guerra 2019 \\
\hline Corallus blombergii & Esmeraldas & Cotacachi Cayapas & 00.583 & -078.683 & & QCAZR10713 & Rodríguez-Guerra 2019 \\
\hline Corallus blombergii & Esmeraldas & Río Bravo & 00.667 & -078.933 & & FHG01074 & Valencia et al. 2008. \\
\hline Rhinobothryum bovallii & Esmeraldas & Río Bogotá & 01.047 & -078.837 & & & $\begin{array}{l}\text { Touzet and Cisneros-Heredia } \\
1998\end{array}$ \\
\hline Rhinobothryum bovallii & Esmeraldas & Zapallo Grande & 00.77 & -078.93 & & QCAZR1595 & $\begin{array}{l}\text { Wallach et al. 2014; Pazmiño- } \\
\text { Otamendi, 2019; }\end{array}$ \\
\hline Rhinobothryum bovallii & Esmeraldas & $\begin{array}{l}\text { Zona Baja de Reserva Ecológica } \\
\text { Cotacachi Cayapas }\end{array}$ & 00.82 & -078.72 & & QCAZR10703 & $\begin{array}{l}\text { Wallach et al. 2014; Pazmiño- } \\
\text { Otamendi } 2019\end{array}$ \\
\hline Rhinobothryum bovallii & Esmeraldas & Reserva Tesoro Escondido & 00.49 & -079.13 & 675 & QCAZR15012 & $\begin{array}{l}\text { Wallach et al. 2014; Pazmiño- } \\
\text { Otamendi } 2019\end{array}$ \\
\hline Rhinobothryum bovallii & Esmeraldas & Reserva Ecológica Mache-Chindul & 00.33 & -079.72 & 427 & QCAZR16951 & $\begin{array}{l}\text { Wallach et al. 2014; Pazmiño- } \\
\text { Otamendi } 2019\end{array}$ \\
\hline Rhinobothryum bovallii & Manabí & Río Cuaque & -00.02 & -080.06 & & QCAZR8962 & $\begin{array}{l}\text { Wallach et al. 2014; Pazmiño- } \\
\text { Otamendi } 2019\end{array}$ \\
\hline Rhinobothryum bovallii & Manabí & Reserva Ecológica Jama Coaque & -00.09 & -080.14 & & QCAZR4652 & $\begin{array}{l}\text { Wallach et al. 2014; Pazmiño- } \\
\text { Otamendi } 2019\end{array}$ \\
\hline Rhinobothryum bovallii & Manabí & Reserva Ecológica Jama Coaque & -00.10 & -080.11 & 392 & QCAZR5889 & $\begin{array}{l}\text { Lynch et al. 2014; Wallach et al. } \\
\text { 2014; Pazmiño-Otamendi } 2019\end{array}$ \\
\hline Rhinobothryum bovallii & Manabí & $\begin{array}{l}\text { A } 15 \text { km de Pedernales, en la vía } \\
\text { a Jama }\end{array}$ & -00.07 & -080.02 & 36 & QCAZR5757 & $\begin{array}{l}\text { Wallach et al. 2014; Pazmiño- } \\
\text { Otamendi } 2019\end{array}$ \\
\hline Spilotes megalolepis & Esmeraldas & Río Mira & 01.208 & -078.519 & & EPN 001305 & Orcés and Almendáriz 1989 \\
\hline Spilotes megalolepis & Santo Domingo de los Tsáchilas & Santo Domingo de los Colorados & -00.250 & -079.150 & 500 & EPN 001300 & Orcés and Almendáriz 1989 \\
\hline Spilotes megalolepis & ElOro & Santa Rosa & -03.433 & -079.967 & 100 & EPN 001302 & Orcés and Almendáriz 1989 \\
\hline Spilotes megalolepis & Manabí & Reserva Ecológica Jama Coaque & -00.109 & -080.117 & 408 & QCAZR11430 & Guerra-Correa, E 2019. \\
\hline
\end{tabular}

Identification. We follow Orcés and Almendariz (1989) in considering S. megalolepis (Fig. 2d) as a valid taxon. The specimen reported herein differs from similar snakes within its estimated range of distribution, such as Clelia equatoriana (Amaral, 1924), by having a metallic black body (brownish black in C. equatoriana); body robust and laterally compressed (not laterally compressed in $C$. equatoriana); head well-differentiated from neck, with yellow marks on supra and infralabials; and tail moderately long, $24-27 \%$ of total length (medium or short in C. equatoriana). The melanistic color differs from other Spilotes species, such as $S$. pullatus (Linnaeus, 1758), by its darker coloration, with small yellow markings anteriorly, absent on the posterior third of the body. Since very little pholidosis data are available for the species, we report herein the scale counts of MZUA.Re0378: postocular 1 ; supralabials 8 , fourth and fifth in contact with the eye; infralabials 8 ; dorsal scales large, except paraventral rows; and dorsal scales at midbody in 14 rows.

Remarks. Another individual was observed in a pad-

dock area, foraging in the undergrowth, but was not collected. Both individuals were near secondary trails used by tourists. Spilotes megalolepis is a little known species, currently reported on the western lowlands of Ecuador, in the provinces of Esmeraldas, Imbabura, Pichincha, Santo Domingo de los Tsáchilas, and El Oro (Boulenger 1898; Orcés and Almendáriz 1989; YánezMuñoz et al. 2009; Ortega-Andrade et al. 2010; GuerraCorrea 2019). Cerro de Hayas is $99 \mathrm{~km}$ north of the southernmost known record of the species (Santa Rosa, province of El Oro), and $220 \mathrm{~km}$ south of the nearest locality to the north (Río Palenque, province of Los Ríos) (Guerra-Correa 2019).

\section{Discussion}

Eighty-four species of reptiles have been previously reported in the province of Guayas (Almendáriz and Carr 1992; Cornejo 2015; Cruz et al. 2017; Torres-Carvajal et al. 2019). Records presented herein reinforce the 
probability that there are still several unreported species of reptiles in Guayas, remaining in small relicts of native vegetation.

We add three additional reptile species to the list of the province of Guayas, including one specimen of Corallus blombergi, categorized as Endangered by IUCN (Cisneros-Heredia 2016). The conservation status of Anolis lyra and Spilotes megalolepis have not been evaluated. Rhinobothryum bovallii has been categorized as Least Concern (Arredondo et al. 2017) because of its large range, but it is necessary to study threats that may affect local populations. These records show the importance of improving our understanding on the distribution patterns of poorly known species. Recently, $C$. blombergi and $R$. bovallii were recorded from Colombia (Pinto-Erazo and Media-Rangel 2018) and Nicaragua (Martínez-Fonseca et al. 2019), respectively.

All four species reported in this study were found in a small private protected area, with small remnants of native riparian vegetation along streams and waterfalls, showing the importance of in-situ private initiatives for the conservation of ecosystems that are highly threatened by anthropogenic activities.

\section{Acknowledgements}

Specimens were collected under permit 008-2015-ICFLO/FAU-DPG/MAE issued by Ministerio del Ambiente. We appreciate the collaboration of Cerro de Hayas Forest's personnel for the facilities provided in the field work. We thank Andreinna Morán, David Reyes, Emily Riquero, Génesis Chonillo, Michelle Vela, Yazmin Cedillo, Yanella Tutivén for field assistance; and Carolina Reyes-Puig and Emilia Peñaherrera (ZSFQ) and the MZUA staff for help in their collections. Work by DFCH and JCS was supported by Universidad San Francisco de Quito (projects HUBI ID 48, 1057, 7703, COCIBA grant). LA was supported by Secretariat of Higher Education, Science, Technology and Innovation and Agencia Nacional de Investigación y Desarrollo. We are grateful to Ross MacCulloch, Alejandro Arteaga and David Salazar-Valenzuela for their time and valuable comments on our manuscript.

\section{Authors' Contributions}

KCG collected and prepared specimens, took photos, wrote and revised the manuscript; DFCH identified specimens, wrote and revised the manuscript; JCS prepared and identified specimens, wrote and revised the manuscript, prepared the maps; LA wrote and revised the manuscript, prepared figures and table. All authors approved the final version of the manuscript.

\section{References}

Almendáriz A, Carr JL (1992) Amphibians and reptile list. January-February trip. In: Parker III TA, Carr JL (Eds) Status of for- est remnants in the Cordillera de la Costa and adjacent areas of southwestern Ecuador. Conservation International, RAP Working Paper 2, Washington, DC, 128-130.

Amaral A do (1924) New genus and species of South American snakes contained in the United States National Museum. Journal of the Washington Academy of Sciences 14: 200-202.

Andersson LG (1916) Notes on the reptiles and batrachians in the Zoological Museum at Gothenburg with an account of some new species. Göteborgs Kungliga Vetenskaps och Vitterhets Samhälles Handlingar: Sjätte Följden, Serien B, 4 (17): 1-41.

Andresen E, Arroyo-Rodríguez V, Escobar F (2018) Tropical biodiversity: the importance of biotic interactions for its origin, maintenance, function, and conservation. In: Dáttilo W, Rico-Gray V (Eds) Ecological networks in the tropics. Springer, Cham, 1-13.

Arredondo JC, Cisneros-Heredia DF, Rivas G, Sunyer J, Townsend JH (2017) Rhinobothryum bovallii. The IUCN Red List of threatened species 2017: e.T177498A1489023. https://doi.org/10.2305/ iucn.uk.2017-2.rlts.t177498A1489023.en. Accessed on: 2020-0519.

Arteaga A, Mebert K, Valencia JH, Cisneros-Heredia DF, Peñafiel N, Reyes-Puig C, Vieira-Fernandes JL, Guayasamin JM (2017) Molecular phylogeny of Atractus (Serpentes, Dipsadidae), with emphasis on Ecuadorian species and the description of three new taxa. ZooKeys 661: 91-123. https://doi.org/10.3897/ zookeys.661.11224

Arteaga A, Salazar-Valenzuela D, Mebert K, Peñafiel N, Aguiar G, Sánchez-Nivicela JC, Pyron RA, Colston TJ, Cisneros-Heredia DF, Yánez-Muñoz MH, Venegas PJ, Guayasamin JM, TorresCarvajal O (2018) Systematics of South American snail-eating snakes (Serpentes, Dipsadini), with the description of five new species from Ecuador and Peru. ZooKeys 766: 79-147. https://doi. org/10.3897/zookeys.766.24523

Ayala-Varela FP, Troya-Rodríguez D, Talero-Rodríguez X, TorresCarvajal O (2014) A new Andean anole species of the Dactyloa clade (Squamata: Iguanidae) from western Ecuador. Amphibian \& Reptile Conservation [Special Section] 8 (1): 8-24.

Boulenger GA (1898) An account of the Reptiles and Batrachians collected by Mr. W. F. H. Rosenberg in western Ecuador. Proceedings of the Zoological Society of London 66 (1): 107-128. https:// doi.org/10.1111/j.1096-3642.1898.tb03134.x

Boulenger GA (1902) Descriptions of new batrachians and reptiles from north-western Ecuador. Annals and Magazine of Natural History (series 7) 9: 51-57. https://doi.org/10.1080/00222930208678538

Brown JH (2014) Why are there so many species in the tropics? Journal of Biogeography 41: 8-22. https://doi.org/10.1111/jbi.12228

Camacho J, Mejía X, León J, Suárez E, Pérez J, Viteri F, Carvajal R (2011) Análisis de vacíos de conservación para la provincia del Guayas. The Nature Conservancy y Gobierno Provincial del Guayas, Guayaquil, 120 pp.

Cisneros-Heredia DF (2016) Corallus blombergi. The IUCN Red List of threatened species 2016: e.T44580012A44580021. https://doi. org/10.2305/iucn.uk.2016-3.rlts.t44580012a44580021.en. Accessed on: 2018-20-07.

Cisneros-Heredia DF, Delia J, Yánez-Muñoz MH, Ortega-Andrade HM (2010) Endemic Ecuadorian glassfrog Cochranella mache is Critically Endangered because of habitat loss. Oryx 44 (1): 114117.

Cisneros-Heredia DF, Romero A (2015) First record of Atractus medusa (Serpentes, Dipsadidae) in Ecuador. Herpetology Notes 8: 417-420.

Cope ED (1862) Contributions to Neotropical saurology. Proceedings of the Academy of Natural Sciences of Philadelphia 14: 176-188.

Cornejo X (2015) Las especies emblemáticas de flora y fauna de la ciudad de Guayaquil y de la provincia del Guayas, Ecuador. Revista Cientifica de Ciencias Naturales y Ambientales 9 (2): 56-71.

Cruz-García FK (2017) Diversidad y preferencia de microhabitats de la herpetofauna del bosque protector "Pedro Franco Dávila" (Jauneche) y del área provincial natural de recreación "Cerro de 
Hayas" (Naranjal). Bachelor's thesis, Facultad de Ciencias Naturales, Universidad de Guayaquil, Guayaquil, 94 pp.

Cruz FK, Urgiles VL, Sánchez-Nivicela JC, Siddons DC, CisnerosHeredia DF (2017) Southernmost records of Hyalinobatrachium fleischmanni (Anura: Centrolenidae). Check List 13 (4): 67-70. https://doi.org/10.15560/13.4.67

Daudin FM (1803) Histoire naturelle, générale et particulière des reptiles. Volume VIII. Dufart, Paris, France, 439 pp

Gallina S, López-González C (2011) Manual de técnicas para el estudio de la fauna. Volúmen I. Universidad Autónoma de QuerétaroInstituto de Ecología, A. C. Querétaro, México, 377 pp.

Guerra-Correa E (2019) Spilotes megalolepis In: Torres-Carvajal O, Pazmiño-Otamendi G, Salazar-Valenzuela D (Eds) Reptiles del Ecuador. Version 2019.0. Museo de Zoología, Pontificia Universidad Católica del Ecuador. http://www.bioweb.bio/faunaweb/ reptiliaweb/FichaEspecie/Spilotes\%20megalolepis. Accessed on: 2019-7-11.

Günther AC (1865) Fourth account of new species of snakes in the collection of the British Museum. Annals and Magazine of Natural History (Series 3) 15: 89-95. https://doi.org/10.1080/00222 936508681770

Harvey MB (2008). New and poorly known Dipsas (Serpentes: Colubridae) from northern South America. Herpetologica 64 (4): 422-451. https://doi.org/10.1655/07-068R1.1

Henderson RW (1997) A taxonomic review of the Corallus hortulanus complex of Neotropical tree boas. Caribbean Journal of Science 33 (3-4): 198-221.

Henderson RW, Höggren M, Lamar WW, Porras LW (2001) Distribution and variation in the Treeboa Corallus annulatus (Serpentes: Boidae). Studies on Neotropical Fauna and Environment 36 (1): 39-47. https://doi.org/10.1076/snfe.36.1.39.8883

Instituto Nacional de Estadísticas y Censos (2018) Censo nacional de población y vivienda 2010. Quito, Ecuador. https://www.indec gob.ar/indec/web/Nivel4-Tema-2-41-135. Accessed on: 2020-0304.

Jadin RC, Altamirano MA, Yánez-Muñoz MH, Smith E (2009) First record of the common house gecko (Hemidactylus frenatus) in Ecuador. Applied Herpetology 6 (2): 193-195. https://doi org/10.1163/157075408X394133

Larrea C, Cuesta F, López A, Greene N, Iturralde P, Maldonado G, Suárez-Duque D (2015) Propuesta de indicadores nacionales de biodiversidad: una contribución para el sistema nacional de monitoreo del patrimonio natural y para la evaluación del impacto de la implementación de la Estrategia Nacional de Biodiversidad y su Plan de Acción 2015-2020. MAE, CONDESAN, GIZ, PNUDFMAM, USAB, Quito, Ecuador, $161 \mathrm{pp}$.

Linnaeus C (1758) Systema naturae per regna tria naturae, secundum classes, ordines, genera, species, cum characteribus, differentiis, synonymis, locis. Editio decima, reformata. Laurentius Salvius, Holmiae, 824 pp.

Lynch RL, Maynard R, Hamilton PS, Biodiversity PEEK (2016). Reptiles de la Reserva Jama Coaque, Manabi, Ecuador. Online photo field guide. https://fieldguides.fieldmuseum.org/sites/default/files/ rapid-color-guides-pdfs/757_ecuador-reptiles_de_jama-coaque. pdf. Accessed on: 2020-19-05.

Ministerio del Ambiente del Ecuador (2012) Sistema de clasificación de los ecosistemas del Ecuador continental. Subsecretaría de Patrimonio Natural, Quito, $136 \mathrm{pp}$.

Martínez-Fonseca JG, Loza J, Fernández M, Salazar-Saavedra M, Sunyer J (2019) First country record of Rhinobothryum bovallii (Andersson, 1916) (Squamata, Colubridae) from Nicaragua Check List 15 (4): 555-563. https://doi.org/10.15560/15.4.555

Mittermeier RA, Robles-Gil P, Hoffmann M, Pilgrim J, Brooks T, Mittermeier CG, Lamoreux J, Da Fonseca GAB (2004) Hotspots revisited. Earth's biologically richest and most endangered terrestrial ecoregions. Conservation International and Agrupación Sierra Madre to Highlight World's "Hotspots", Monterrey, Mexico, $392 \mathrm{pp}$.
Mittermeier RA, Turner WR, Larsen FW, Brooks TM, Gascon C (2011) Global biodiversity conservation: the critical role of hotspots. In: Zachos FE, Habel JC (Eds) Biodiversity hotspots. Springer-Verlag, Berlin, 3-22. https://doi.org/10.1007/978-3-64220992-5 1

Orcés G, Almendáriz A (1989) Acerca de la Sistemática de Spilotes megalolepis Gunther (Serpentes: Colubridae). Revista Politécnica 14 (2): 69-73.

Ortega-Andrade HM, Meza-Ramos P, Cisneros-Heredia DF, YánezMuñoz M, Altamirano-Benavides M (2010) Los anfibios y reptiles del Chocó esmeraldeno. In: Serie herpetofauna del Ecuador: El Chocó Esmeraldeño. Museo Ecuatoriano de Ciencias Naturales, Quito, 95-232.

Passos P, Cisneros-Heredia DF, Rivera DE, Aguilar C, Schargel WE (2012) Rediscovery of Atractus microrhynchus and reappraisal of the taxonomic status of $A$. emersoni and A. natans (Serpentes: Dipsadidae). Herpetologica 68 (3): 375-392. https://doi.org/ 10.1655/herpetologica-d-11-00078.1

Pazmiño-Otamendi G (2019) Rhinobothryum bovallii In: Torres-Carvajal O, Pazmiño-Otamendi G, Salazar-Valenzuela D (2019) Reptiles del Ecuador. Version 2019.0. Museo de Zoología, Pontificia Universidad Católica del Ecuador. https://bioweb.bio/faunaweb/ reptiliaweb/FichaEspecie/Rhinobothryum\%20bovallii. Accessed on: 2019-7-11

Pérez-Santos C, Moreno AG (1991) Serpientes de Ecuador. Monografie XI, Museo Regionale di Scienze Naturali, Torino, $538 \mathrm{pp}$.

Peters JA (1960). The snakes of the subfamily Dipsadinae. Miscellaneous Publications, Museum of Zoology, University of Michigan 114: 1-224.

Pinto-Erazo MA, Medina-Rangel GF (2018) First record of Corallus blombergi (Rendahl \& Vestergren, 1941) (Serpentes, Boidae) from Colombia. Check List 14 (1): 183-188. https://doi.org/ 10.15560/14.1.183

Poe S, Velasco J, Miyata K, Williams EE (2009) Descriptions of two nomen nudum species of Anolis lizard from northwestern South America. Breviora 516 (1): 1-16. https://doi.org/10.3099/0006-96 98-516.1.1

PyronRA, Guayasamin JM,PeñafielN, BustamanteL, Arteaga A(2015) Systematics of Nothopsini (Serpentes, Dipsadidae), with a new species of Synophis from the Pacific Andean slopes of southwestern Ecuador. ZooKeys 541: 109-147. https://doi.org/10.3897/zoo keys. 541.6058

QGIS Development Team (2019) QGIS Geographic Information System. Open Source Geospatial Foundation Project. http://qgis.os geo.org. Accessed on: 2019-12-20.

Rendahl H, Vestergren G (1941) Notes on Colombian snakes. Arkiv för Zoologi 33A: 1-16.

Reyes-Puig C, Almendáriz AC, Torres-Carvajal O (2017) Diversity, threat, and conservation of reptiles from continental Ecuador. Amphibian \& Reptile Conservation 11 (2): 51-58.

Reyes-Puig C, Bittencourt-Silva GB, Torres-Sánchez M, Wilkinson M, Streicher JW, Maddock ST, Kotharambath R, Müller H, Larrea FNA, Almeida-Reinoso D, Ron SR, Cisneros-Heredia DF (2019) Rediscovery of the Endangered Carchi Andean Toad, Rhaebo colomai (Hoogmoed, 1985), in Ecuador, with comments on its conservation status and extinction risk. Check List 15 (3): 415-419. https://doi.org/10.15560/15.3.415

Rodríguez-Guerra A (2019) Corallus blombergi In: Torres-Carvajal O, Pazmiño-Otamendi G, Salazar-Valenzuela D (2019) Reptiles del Ecuador. Version 2019.0. Museo de Zoología, Pontificia Universidad Católica del Ecuador. https://bioweb.bio/faunaweb/ reptiliaweb/FichaEspecie/Corallus\%20blombergi. Accessed on: 2020-3-12.

Salazar-Valenzuela D, Martins A, Amador-Oyola L, Torres-Carvajal O (2015) A new species and country record of threadsnakes (Serpentes: Leptotyphlopidae: Epictinae) from northern Ecuador. Amphibian \& Reptile Conservation 8 (1): 107-120 (e89). 
Scopoli GA (1785) Deliciae florae et faunae insubricae. Nabu Press, $182 \mathrm{pp}$.

Torres-Carvajal O, Yánez-Muñoz MH, Quirola D, Smith EN, Almendáriz A (2012) A new species of blunt-headed vine snake (Colubridae, Imantodes) from the Chocó region of Ecuador. ZooKeys 244: 91-110. https://doi.org/10.3897/zookeys.244.3950

Torres-Carvajal O, Venegas PJ, de Queiroz K (2015) Three new species of woodlizards (Hoplocercinae, Enyalioides) from northwestern South America. ZooKeys 494: 107-132. https://doi.org/10. 3897/zookeys.494.8903

Torres-Carvajal O, Pazmiño-Otamendi G, Salazar-Valenzuela D (2019) Reptiles of Ecuador: a resource-rich online portal, with dynamic checklists and photographic guides. Amphibian and Reptile Conservation 13 (1): 209-229.

Torres-Carvajal O, Pazmiño-Otamendi G, Salazar-Valenzuela D (2020) Reptiles del Ecuador. Version 2020.0. Museo de Zoología, Pontificia Universidad Católica del Ecuador. https://bioweb.bio/ faunaweb/reptiliaweb. Accessed on: 2020-5-12.

Touzet JM, Cisneros-Heredia DF (1998) Las serpientes del género Rhinobothryum bovallii en Ecuador con notas sobre su manejo en cautiverio. Reptinotas 4: 3 .

Valencia J, Arbeláez E, Garzón K (2008) Notes on Corallus blom- bergi (Rendahl \& Vestergren, 1941) from Ecuador. Herpetozoa 21 (1-2): 91-94

Wallach V, Williams KL, Boundy J (2014) Snakes of the World: A catalogue of living and extinct species. CRC Press Boca Raton, Florida, USA, 1227 pp.

Yánez-Muñoz MH, Meza-Ramos PA, Ramírez SM, Reyes-Puig JP, Oyagata LAC (2009) Anfibios y reptiles del Distrito Metropolitano de Quito (DMQ). In: Guía de Campo de los Pequeños Vertebrados del Distrito Metropolitano de Quito (DMQ). Publicación Miscelánea $\mathrm{N}^{\circ} 5$, Serie de Publicaciones del Museo Ecuatoriano de Ciencias Naturales (MECN), Fondo Ambiental del MDMQ, Imprenta Nuevo Arte, Quito, Ecuador, 9-52.

Yánez-Muñoz MH, Sánchez JC, López K, Rea E, Meza-Ramos PA, Oyagata LA, Guerrero P (2014) Ampliaciones del rango de distribución de algunas especies de anfibios y reptiles en el suroccidente de Ecuador. Avances de Ciencias e Ingenierías 6 (1): B2B5. https://doi.org/10.18272/aci.v6i1.151

Yánez-Muñoz MH, Reyes-Puig C, Reyes-Puig JP, Velasco JA, AyalaVarela F, Torres-Carvajal O (2018) A new cryptic species of Anolis lizard from northwestern South America (Iguanidae, Dactyloinae). ZooKeys 794: 135-163. https://doi.org/10.3897/zoo keys.794.26936 